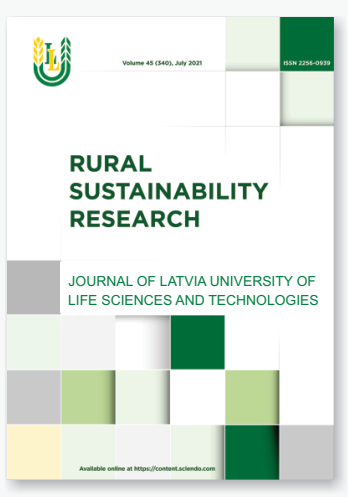

\title{
Pre-treatment Effect on Physical and Microbial Parameters of Smoked Baltic Sprats
}

\author{
*Santa Puke, Ruta Galoburda \\ Latvia University of Life Sciences and Technologies, 22 Rigas street, Jelgava, Latvia
}

\begin{abstract}
Smoked sprats are delicious and nutritionally valuable product. Besides protein, it contains high amount of unsaturated fatty acids and fat soluble vitamins. Nowadays, human interest for fish product consumption is increasing. It leads to the demand for increased shelf life of the smoked sprats. One way to prolong the shelf life is to use some pre-treatment prior to smoking. The aim of study was to analyse the effect of pre-treatment on smoked Baltic sprat quality and microbiological parameters. Various compositions of brine using salts $\left(\mathrm{NaCl}, \mathrm{CaCl}_{2}\right)$ and acetic acid in different proportions were used for fresh sprat pre-treatment. Pre-treatment had the influence on physical parameters; pre-treated samples had higher salt and lower moisture content, and lower $\mathrm{pH}$, which allowed prolonging the shelf life of smoked sprats. The highest $\mathrm{pH}$ was in the control sample 6.6, and it allowed growth of yeasts, moulds, Pseudomonas spp., and mesophilic and facultative anaerobic microorganisms. The results demonstrated that after two-week storage of the smoked sprats the growth of moulds $\left(1 \times 10^{2} \mathrm{CFU}\right.$ $\mathrm{g}^{-1}$ ) was observed only for smoked sprats without pre-treatment (control sample), indicating the positive effect of pre-treatment. Salmonella spp., Clostridium perfingens, Listeria monocytogenes, and Escherichia coli were not detected in any of the analysed samples. After pre-treatment in brine, containing combination of $\mathrm{NaCl}$ and $\mathrm{CaCl}_{2}$, smoked fish had darker colour compared to control sample or sample with sodium chloride only. Any of applied pre-treatments, except brine containing NaCl, made firmer texture of the smoked fish.
\end{abstract}

Keywords: smoked sprats, microorganisms, physical parameters, texture, colour.

\section{Introduction}

Sprats (Sprattus sprattus balticus) are nutritionally valuable product, which is rich in proteins, contains unsaturated fats, fat soluble vitamins, and essential minerals (Babikova et al., 2020). According to Central Statistical Bureau of Latvia the amount of sprats caught from 2019 till 2020 decreased from 38.7 till 28.9 thousand million tons in Latvia, but it is foreseen that fishing option for fisherman's will increase in 2021 for sprats by $6 \%$ (till 30817 tons) (Muceniece, 2020). Fish were eaten already since ancient times, it was valuable and available product for everybody. Nowadays the demand for variety of fish products increases. However, it is hard to ensure the required amount and quality, because of fish spoilage, which starts soon after the catch. Therefore, it is necessary to refrigerate fish immediately after it is being caught to prevent microbial spoilage or ensure higher safety.

Smoking is one of the oldest methods, which has been used for fish processing to obtain delicious products. Traditional smoking is also used to preserve fish, when smoking compounds such as phenols have a considerable importance for the preservation and sensory properties (flavour and colour) of the smoked products (Sérot et al., 2004). There are identified at least 400 different compounds in wood smoke (acids, alcohols, esters, etc.), and each of them has a functional role in smoking process (Toledo, 2008). Typically, smoked and preserved fish products have very short shelf life, from hours till some days, that means it is hard to be stored longer or exported to other countries. Fresh smoked sprat shelf life can be a few days $(72 \mathrm{~h})$ till one week according to the manufacturer's internal regulations, but for sprats to be used in canned product 'Smoked sprats in oil', storage time should not exceed $16 \mathrm{~h}$ ("Requirements for Food Quality Schemes, Procedures for the Implementation, Operation, Monitoring, and Control Thereof," 2014). The use of pre-treatment allows to ensure microbiological safety of sprats for 2 weeks. Therefore, it is necessary to apply additional preservation for fish products to ensure safety and good quality of the products with sufficient shelf life. 
Fish is highly perishable product, and it may have different microflora depending on the environmental factors and chemical composition of fish (Tahsin et al., 2017). The microbiological spoilage is the main process which affects fresh fish quality and later also quality of the produced fish products. Microbial spoilage affects the sensorial properties, which initially cannot be seen. Total plate count (TPC), Enterobacteriaceae and Escherichia coli are often used as the indicators to assess the quality according to the legislation on safety of sea foods handling hygiene. TPC is used to assess the general microbiological quality of fish and can be a quality indicator for raw fish microbiological quality according to the EC Regulations 2073/2005; 852/2004; $853 / 2004 ; 1441 / 2007$. Several pathogenic bacteria may either be present in the environment or contaminate fish during handling. Salmonella and Listeria monocytogenes are reported to cause foodborne infections in humans by the ingestion of raw or inadequately processed contaminated fish or fish products (Eizenberga et al., 2015). Contamination by microorganisms can cause different human infections, which can even be lethal. One of the fish spoilers in cold storage process is Pseudomonas spp., which is harmful due to the enzyme produced toxic metabolites. Production of various alcohols, aldehydes and ketones (ethanol, 2-methylbutanal, 2-heptanone, 3-hydroxy-2-butanone or other) has been reported as a result of metabolic activity by microorganisms, such as Pseudomonas spp. or Enterobacteriaceae (Parlapani et al., 2014). Typically for smoked fish the Pseudomonas spp. are not detected (Olayemi, Raji, \& Adedayo, 2012). Vibrio parahaemolyticus is a halophilic bacterium usually is present in the marine environment (Wawire et al., 2019). To decrease or stop microbiological spoilage in fresh fish, it is necessary to control other physical parameters, which can ensure stable quality during processing of fish such as $\mathrm{pH}$, amount of added salt, moisture, and storage conditions (temperature and time). According to Yanar, Çelik, \& Akamca (2006) the brine concentration, brine composition and time have influence on the fish product textural properties and microbiota. There is a trend to reduce amount of preservatives used in the production. However, before reducing the amount of preservatives, the fish processing industry needs to estimate survival and growth of microorganisms affecting the changes in product quality and safety.

The antimicrobial effect of organic acids depends on the nature of the acid, i.e. a degree of dissociation, nature of food and microorganisms. The use of pre-treatment has not only effect on microbiological properties, but it also affects the physical parameters. Preservation of fish inhibits bacterial growth in fish if acid is added in a brine. As a result, it reduces $\mathrm{pH}$, and increases salt amount in fish flesh, it ensures longer product safety (Ayuba, Alhassan, \& Jimmy, 2013) and makes also textural changes of the product. Acid and salt diffuse in the fish flesh; decrease water holding capacity bonds and makes firmer texture and has influence on water activity. Low water activity together with low $\mathrm{pH}$ reduce microbiological growth (Kuda et al., 2013). Sprats are fatty fish, fat content even in spawning season can be more than $10 \%$ (Timberg et al., 2011), and as fatty fish it absorbs less salt than lean fish (Ruiz-Alonso et al., 2021).

One of the problems to ensure stable quality of the final product is unstable quality of the fresh fish (nutritional elements protein, lipids, water) during the season. The changes are observed due to the variability in fish chemical composition. In the feeding season (July till October) sprats contain more lipids (about 15\%), but less moisture (about $66 \%$ ) compared to the spawning season (March till June) were lipid content is approximately $5 \%$, but moisture till $77 \%$ (Usydus, Szlifder-Richert, \& Adamczyk, 2012). Some studies show that using pre-treatment it is possible to improve quality of products (Sengun et al., 2021) and fish, brining inhibits microorganism growth (Babikova et al., 2020). Typically used materials, which have no impact on organoleptic attributes and are available to producers, are acids, salts, and other additives.

The aim of the study was to analyse the effect of pretreatment on smoked Baltic sprat quality and microbiological parameters.

\section{Materials and Methods}

Fish. In the experiments, fresh Baltic Sea sprats (Sprattus sprattus balticus) caught in March, 2021 were used. Fish were transported to producing company within 48 hours, the temperature inside the fish was kept below $2 \pm 2{ }^{\circ} \mathrm{C}$. Fish was of the freshness category A and size category for sprats 1 (Council of the European Union, 1997). Fresh sprats were stored till processing (pre-treatment) in a container covered with ice (proportion fish to ice was $1: 3$ ) at $2 \pm 2{ }^{\circ} \mathrm{C}$ in a refrigerated room not more than 48 hours to ensure fresh fish quality.

Pre-treatment materials. As the pre-treatment materials were used, food grade acetic acid $\mathrm{CH}_{3} \mathrm{COOH}$ (E260), acetic acid amount 80\%, (Safrāns, Latvia), $\mathrm{NaCl}$ (Mozirsol, Belarus), granulated $\mathrm{CaCl}_{2}$ (E509, $\mathrm{CaCl}_{2}$ content $(97 \%)$, $110.99 \mathrm{~g} \mathrm{~mol}^{-1}$ ) (Lachner, Czech Republic). The additives $\mathrm{CH}_{3} \mathrm{COOH}$ and $\mathrm{CaCl}_{2}$ are food additives and can be used in quantum satis.

Fish sample preparation using pre-treatment. The brine solutions were prepared using different proportions of ingredients combined with cold water, no added ice (Table 1). The concentrations were selected according to the production experience and preliminary tests to find the best concentration of brine providing sufficiently firm fish texture. Six different pre-treatment methods were applied. Fish was soaked in proportion fish: brine (1:2) for 30 minutes periodically stirring, ensuring temperature not higher than $4 \pm 2{ }^{\circ} \mathrm{C}$, if necessary, chopped ice was added. Chopped ice can be used as an additional tool to ensure the required temperature. The sample without any pre-treatment was used as a control sample.

\section{Composition of the brine used for the pre-treatment of fresh sprats}

Table 1

\begin{tabular}{|l|c|c|c|}
\hline \multirow{2}{*}{ Identification of samples } & \multicolumn{3}{|c|}{ Ingredients per $1 \mathrm{~kg}$ of brine, $\mathrm{g}$} \\
\cline { 2 - 4 } & $\mathrm{NaCl}$ & $\mathrm{CaCl}_{2}$ & $\mathrm{CH}_{3} \mathrm{COOH}^{2}$ \\
\hline
\end{tabular}




\begin{tabular}{|c|c|c|c|}
\hline Control & - & - & - \\
\hline $\mathrm{Na}$ & 29.13 & - & - \\
\hline $3 \mathrm{Na} 2 \mathrm{Ca}$ & 28.64 & 16.71 & - \\
\hline $2 \mathrm{Na3Ca}$ & 16.70 & 28.64 & 9.90 \\
\hline Ace & - & - & 7.14 \\
\hline NaAce & 28.84 & - & 7.14 \\
\hline CaAce & - & 28.84 & \\
\hline
\end{tabular}

After soaking in brine, fish was smoked in the hot smoking chamber (Rauch Spectrum, Germany) of the fish producing company using beech wood chips (with moisture below $15 \%)$. The main parameters for hot smoking $\left(80^{\circ} \mathrm{C}\right)-$ drying (35 minutes), cooking (10 minutes), steaming (2 minutes), adding smoke (10 minutes), and cooling (5 minutes). After smoking, fish was stored till at least $10^{\circ} \mathrm{C}$ was reached and then placed in cutting machine to cut heads and tails (if necessary for packaging) and moved to the cooling chambers in plastic (HDPE) boxes for storage $\left(2 \pm 2{ }^{\circ} \mathrm{C}\right)$. Each treatment was repeated in triplicate to make an average sample for analyses, the experiment was done in smoked fish producing company in Latvia. Samples were stored till analysing (next day after smoking, one week and two weeks) at $2 \pm 2{ }^{\circ} \mathrm{C}$.

Determination of physical parameters. All smoked fish samples were analysed one day after smoking. The main control parameters were water activity $\left(\mathrm{a}_{\mathrm{w}}\right)$ (method PN-ISO 21807:2005), pH (method PN-A-86782:1987), moisture content (method PN-A-86783:1962) and sodium chloride calculated from $\mathrm{Na}$ content $(\mathrm{Na} \times 2.5)$ according to the test report, received from the external laboratory J. S. Hamilton (Poland). The samples were delivered to the laboratory in a cool box to ensure the same temperature as in the storage room $\left(2 \pm 2{ }^{\circ} \mathrm{C}\right)$. Fresh smoked sprats were analysed for firmness using TA.HD.Plus texture analyser (Stable Microsystems, UK) equipped with Warner-Bratzler blade set with knife and colour in CIE L*a*b* system using Color Tec - PCM colour meter (Accuracy Microsensors Inc., USA) with software Color Tec-Color Soft QCW.

Determination of microbiological parameters. Microbiological parameters of sprats were analysed in the external laboratory J. S. Hamilton, one day after smoking and then after one and two-week storage to evaluate changes during storage. The samples were randomly selected from the plastic boxes stored in the cooling chamber $\left(2 \pm 2{ }^{\circ} \mathrm{C}\right)$. The smoked sprats with different pre-treatments were analysed to check influence of pre-treatment method on the microbiological parameters indicated in Table 2 .

\section{The methods used for the microbiological evaluation of smoked sprats}

\begin{tabular}{|l|c|}
\hline \multicolumn{1}{|c|}{ Microbiological parameters } & Test method \\
\hline Yeast & LVS ISO 21527-2:2008 \\
\hline Moulds & LVS ISO 21527-2:2008 \\
\hline Total plate count & LVS EN ISO 4833-1:2014 \\
\hline Bacillus cereus & LVS EN ISO 7932:2005 \\
\hline Salmonella spp. & LVS EN ISO 6579-1:2017 \\
\hline Listeria monocytogenes & LVS EN ISO 11290-2:2017 \\
\hline Pseudomonas spp. & PN-EN ISO 13720:2010 \\
\hline Clostridium perfingens & LVS EN ISO 7937:2005 \\
\hline$\beta$-glucuronidase positive Escherichia coli & LVS ISO 16649-2:2007 \\
\hline Vibrio parahaemolyticus & PN-EN ISO 21872-1:2017-10 \\
\hline
\end{tabular}


Statistical analyses. Each sample was tested in triplicate, except colour and firmness, which were analysed in seven repetitions. The average values are reported. Averages and standard deviations were calculated using MS Office Excel 2016 (Microsoft, USA) software. Statistical analysis was performed using XLSTAT 2021 (Addinsoft Inc, USA). Comparisons were done by one-way ANOVA followed by ttest at the significance $\mathrm{p}<0.05$.

\section{Results and Discussion}

\section{Pre-treatment effect on physical parameters} of smoked sprats

Microbiological changes - spoilage, starts from the internal organs and gills, skin, and gut soon after fish have been caught. It is important to cool quickly to stop spoilage and to process fish in the fastest way to ensure the quality of finished products without any changes (Svanevik \& Lunestad, 2011). Further the pre-treatment was applied with the aim to improve physical and microbiological parameters of the smoked sprats. In the sprat, smoking was used at least at $80^{\circ} \mathrm{C}$ temperature; therefore, a lot of changes occurred in fish - changes of textural, flavour, and microbiological parameters. Because the product was cooked, proteins were denatured, and it decreased moisture content. Thus, it is possible to prolong the shelf life of smoked sprats and maintain the quality for longer time.

The $\mathrm{pH}$ of fresh fish is 7, which after smoking decreased till 6.6 in the sample without pre-treatment (Table 3). The smoke led to a drop in $\mathrm{pH}$, compared with the raw material values possibly due to the greater ionic strength of the internal solution in fish muscle cells associated with salt uptake (Rizo et al., 2016). Pre-treatment reduced $\mathrm{pH}$ of smoked sprats depending on the brine composition. The lowest $\mathrm{pH}$ was $5.6 \pm 0.2$ in sprats treated with calcium chloride and acetic acid (CaAce) or $5.8 \pm 0.2$ when treated with brine containing the combination of sodium chloride and calcium chloride $(2 \mathrm{Na} 3 \mathrm{Ca})$. The most similar $\mathrm{pH}$ to control sample was in fish treated with sodium chloride only $(6.4 \pm 0.2)$, which increased the amount of salt in fish. Typically during storage the $\mathrm{pH}$ increases, and it reflects the production of alkaline bacteria metabolites which starts to spoil the fish and starts increasing total volatile basic nitrogen (Abbas et al., 2008). Rizo et al. (2016) compared smoked cod with fresh cod, the smoking reduced moisture, increased the $\mathrm{NaCl}$ concentration and lowered the $\mathrm{a}_{\mathrm{w}}$ values probably due to $\mathrm{NaCl}$ uptake and dehydration. Analysing differences in water activity and moisture content among experimental samples after various pre-treatment methods no differences between average values was found, but significant differences were established for $\mathrm{pH}$ and sodium chloride content.

Brining reduced $\mathrm{pH}$, water activity and increased salt content in flesh, the moisture decrease is affected by salt action and reduced water absorption availability. Acetic acid with or without salt can also inhibit microbiological growth and ensure longer shelf life of product (Kim \& Lee, 2021). According to Abbas et al. (2009), water activity with moisture content has nonlinear relationship.

Physical parameters of smoked sprats

Table 3

\begin{tabular}{|c|c|c|c|c|}
\hline ID of samples & $\mathrm{pH}$ & Water activity & Moisture, \% & Sodium chloride, $\%$ \\
\hline Control & $6.6 \pm 0.2 \mathrm{a}$ & $0.951 \pm 0.028 \mathrm{a}$ & $67.5 \pm 3.4 \mathrm{a}$ & $0.35 \pm 0.07 \mathrm{c}$ \\
\hline $\mathrm{Na}$ & $6.4 \pm 0.2 \mathrm{ab}$ & $0.948 \pm 0.028 \mathrm{a}$ & $66.7 \pm 3.3 \mathrm{a}$ & $0.70 \pm 0.13 \mathrm{ab}$ \\
\hline $3 \mathrm{Na} 2 \mathrm{Ca}$ & $6.0 \pm 0.2 \mathrm{bc}$ & $0.937 \pm 0.028 \mathrm{a}$ & $62.5 \pm 3.1 \mathrm{a}$ & $0.90 \pm 0.17 \mathrm{a}$ \\
\hline $2 \mathrm{Na} 3 \mathrm{Ca}$ & $5.8 \pm 0.2 \mathrm{c}$ & $0.949 \pm 0.028 \mathrm{a}$ & $61.5 \pm 3.1 \mathrm{a}$ & $0.62 \pm 0.12 \mathrm{ab}$ \\
\hline $\mathrm{Ace}$ & $6.1 \pm 0.2 \mathrm{bc}$ & $0.950 \pm 0.028 \mathrm{a}$ & $65.7 \pm 3.3 \mathrm{a}$ & $0.32 \pm 0.06 \mathrm{c}$ \\
\hline $\mathrm{NaAce}$ & $6.0 \pm 0.2 \mathrm{bc}$ & $0.948 \pm 0.028 \mathrm{a}$ & $62.9 \pm 3.1 \mathrm{a}$ & $0.85 \pm 0.16 \mathrm{ab}$ \\
\hline $\mathrm{CaAce}$ & $5.6 \pm 0.2 \mathrm{~d}$ & $0.946 \pm 0.028 \mathrm{a}$ & $61.7 \pm 3.1 \mathrm{a}$ & $0.40 \pm 0.08 \mathrm{bc}$ \\
\hline
\end{tabular}

Average value $(\mathrm{n}=3) \pm \mathrm{SD}$. Means with the same letter in a column are not significantly different at $\mathrm{p}<0.05$ ( $\mathrm{t}$-test).

In our study, smoked fish had high moisture content - up to $67 \%$ for control sample (Table 3 ), but it may vary by smoking technologies, fish type and size. Salt and acids has the effect on proteins, it results in the destruction of proteins in brine while salt enters the muscle tissue (Martinez et al., 2012). The highest salt content among the studied samples was $0.90 \pm 0.17$ in sample $3 \mathrm{Na} 2 \mathrm{Ca}$. The use of acids or salts decrease smoked fish moisture content, because the additives diffuse in fish tissues, decrease juiciness, acetic acid degrades the connective tissue and its membranes, decreasing the water holding capacity with protein denaturation. The sample with the highest salt content $0.90 \%$ had the lowest water activity 0.937 , while for the control sample with the lowest salt content, water activity was the highest $(0.951 \pm 0.028)$, which is in agreement with the study of Ruiz-Alonso et al. (2021), who reported that increasing the salt amount makes 
lower water activity. Moisture decrease is similar using salt or acid because it starts enzymatic process and microbiological changes. Salt amount has the impact on bacteria growth. The addition of $\mathrm{NaCl}$ at a concentration of about $5.5-6.5 \% \mathrm{w} / \mathrm{w}$, decreases the water activity $\left(\mathrm{a}_{\mathrm{w}}\right)$ (Timberg, 2012).

Smoking of fish is one of the conventional procedures for reducing water activity $\left(a_{w}\right)$ which expresses the moisture requirement of microorganisms. This is an effective tool in fish preservation as the nature and extent of fish spoilage depends on water activity, an important constituent of biological systems. Bjørnevik et al. (2018) analysed hot smoked fish and revealed that water activity must be less than 0.85 to make products stable at room temperature for a longer time. In fresh fish, water activity is close to 1 , but for fresh sprats 0.97 , and during processing it is typically decreased. The water activity could vary even if the moisture content does not change significantly it can be accelerated by up-take of moisture from the environment by the product, thus changing the water activity of the product during storage before equilibrium is reached (Wawire et al., 2019). Water activity indicates possibility of microbiological activity. During storage it typically increases because these are good conditions (temperature, moisture, oxygen availability, time of storage, acidity and food nutrition's for future development) for microorganism growth. The highest water activity $(0.951 \pm 0.028)$ was observed in control sample without pre-treatment, but the lowest - using $3 \mathrm{Na} 2 \mathrm{Ca}$ $(0.937 \pm 0.028)$; however, differences were not significant at $p$ $<0.05$. It shows that using pre-treatment it is possible to reduce $\mathrm{a}_{\mathrm{w}}$ value, which is important for the microbiological activity reduction. Timberg (2012) found out when $a_{w}$ decreases to 0.96 , some Gram-negative bacteria are inhibited (e. g., Pseudomonas spp.) but some other may grow, while (Abbas et al., 2009) reported, that water activity at least 0.91 is required for microorganism growth, and below 0.90 a lot of bacteria cannot grow, only Staphylococcus aureus can grow till 0.85 . Preservation was achieved by reducing the marinated product's $\mathrm{pH}$ value and water activity and increasing the salt content thereby inhibiting all microbial growth across all curing stages. Loss of moisture from the fish flesh caused by acetic acid decreased the total water content of sprat fillets. Babikova et al. (2020) also reported that water activity of marinated anchovies (Engraulis anchoita) was reduced from 0.99 to 0.94 .

The smoked fish colour (Table 4) depends on smoking technique and also on $\mathrm{pH}$, and salt content. There exists very strong linear correlation between $\mathrm{pH}$ and moisture $(\mathrm{r}=0.93)$ increasing moisture the $\mathrm{pH}$ increases in linear proportion. Chan et al. (2020) finalised, higher $\mathrm{pH}$ results in darker colour (lower $\mathrm{L}^{*}$ value), but in the current research, there was no correlation between these parameters. Darker sprats were the ones, which were treated using $3 \mathrm{Na} 2 \mathrm{Ca}$ and $2 \mathrm{Na} 3 \mathrm{Ca}$ with $\mathrm{pH}$ 6 and 5.8, respectively, were increases $\mathrm{pH}$, the same was observed by, no browning was observed when different salt at pH 4.5 was used. The control sample which had the highest $\mathrm{pH} 6.6$ had an average $\mathrm{L}^{*}$ value but $3 \mathrm{Na} 2 \mathrm{Ca}$ and $2 \mathrm{Na} 3 \mathrm{Ca}$ had similar results for samples $\mathrm{L}^{*}$ value. Redness $\left(\mathrm{a}^{*}\right)$ had a weak negative correlation with water activity $(r=-0.55)$, lower water activity increased redness of fish, for other colour parameters no correlations with physical parameters were established. In the production process (temperature above 70 ${ }^{\circ} \mathrm{C}$ ) of smoking Maillard reaction also occurs, which affects smoked fish quality, changes organoleptic parameters, colour intensity and also protein functionality (heat stability and solubility of protein, textural properties). Metal ions have the ability to inhibit or promote production of Maillard reaction browning products. $\mathrm{Ca}^{+}$ions and $\mathrm{Na}+$ together with $\mathrm{Cl}$ slow down browning (Kwak \& Lim, 2004). Higher salt concentrations slow down browning reactions (Yamaguchi et al., 2009).

Colour and texture of smoked fish after pre-treatment and smoking

Table 4

\begin{tabular}{|l|c|c|c|c|c|}
\hline \multirow{2}{*}{$\begin{array}{c}\text { ID of } \\
\text { sample }\end{array}$} & \multicolumn{3}{|c|}{ Colour } & \multicolumn{2}{c|}{ Texture } \\
\cline { 2 - 6 } & $\mathrm{L}^{*}$ & $\mathrm{a}^{*}$ & $\mathrm{~b}^{*}$ & $\begin{array}{c}\text { Work of shear, } \\
\mathrm{N} \mathrm{mm}^{-1} \mathrm{~s}\end{array}$ & $\begin{array}{c}\text { Cutting strength, } \\
\mathrm{N} \mathrm{mm}^{-1}\end{array}$ \\
\hline Control & $57.28 \pm 6.7 \mathrm{a}$ & $-5.14 \pm 6.2 \mathrm{a}$ & $15.54 \pm 9.0 \mathrm{c}$ & $1.27 \pm 0.28 \mathrm{~b}$ & $0.54 \pm 0.12 \mathrm{c}$ \\
\hline $\mathrm{Na}$ & $63.65 \pm 11.8 \mathrm{a}$ & $-13.84 \pm 13.5 \mathrm{~b}$ & $32.42 \pm 12.8 \mathrm{ab}$ & $0.94 \pm 0.21 \mathrm{~d}$ & $0.37 \pm 0.08 \mathrm{~d}$ \\
\hline $3 \mathrm{Na} 2 \mathrm{Ca}$ & $45.58 \pm 8.9 \mathrm{~b}$ & $-1.04 \pm 12.1 \mathrm{a}$ & $26.20 \pm 15.6 \mathrm{abc}$ & $2.38 \pm 0.92 \mathrm{abc}$ & $1.05 \pm 0.49 \mathrm{abc}$ \\
\hline $2 \mathrm{Na} 3 \mathrm{Ca}$ & $47.59 \pm 13.9 \mathrm{~b}$ & $-6.9 \pm 9.9 \mathrm{ab}$ & $16.88 \pm 12.2 \mathrm{bc}$ & $1.42 \pm 0.25 \mathrm{bc}$ & $0.62 \pm 0.13 \mathrm{ac}$ \\
\hline Ace & $52.66 \pm 13.0 \mathrm{ab}$ & $-6.71 \pm 5.9 \mathrm{~b}$ & $26.56 \pm 5.1 \mathrm{ab}$ & $1.75 \pm 0.30 \mathrm{abc}$ & $0.71 \pm 0.14 \mathrm{abc}$ \\
\hline NaAce & $62.89 \pm 10.2 \mathrm{a}$ & $-8.32 \pm 10.4 \mathrm{~b}$ & $17.19 \pm 13.0 \mathrm{abc}$ & $1.76 \pm 0.54 \mathrm{abc}$ & $0.71 \pm 0.24 \mathrm{abc}$ \\
\hline CaAce & $61.19 \pm 10.5 \mathrm{a}$ & $-7.19 \pm 16.2 \mathrm{~b}$ & $26.38 \pm 17.2 \mathrm{abc}$ & $1.73 \pm 0.26 \mathrm{abc}$ & $0.82 \pm 0.12 \mathrm{abc}$ \\
\hline
\end{tabular}


Average value $(n=7) \pm$ SD. Samples with the same letter have no significant difference in a column at $\mathrm{p}<0.05$ according to t-test.

Smoked sprats texture was affected by $\mathrm{pH}$ and moisture content. The decreased moisture content and lower $\mathrm{pH}$ resulted in a firmer texture. Work of shear differed between $1.27 \pm 0.28 \mathrm{~N} \mathrm{~mm}^{-1} \mathrm{~s}$ (control) and $1.76 \pm 0.54 \mathrm{~N} \mathrm{~mm}^{-1} \mathrm{~s}$, when brine contained acetic acid. The use of acids in the pretreatment increases the ionic strength (Çağlak, 2015) and decreases $\mathrm{pH}$ values, which makes firmer texture. In the sample with the highest salt content Ruiz-Alonso et al. (2021) obtained similar results for work of shear fillets with brining at $7 \%$ and $10 \%$ salt were firmer than $5 \%$ treated fillet samples because of salt penetration in fish flesh. The combined use of salt and acetic acid increased work of shear more than any separate pre-treatment agent. Increased sodium chloride amount in sample $3 \mathrm{Na} 2 \mathrm{Ca}$ made texture firmer $(2.38 \pm 0.92 \mathrm{~N}$ $\left.\mathrm{mm}^{-1} \mathrm{~s}\right)$ than the texture of control sample without pretreatment $\left(1.27 \pm 0.25 \mathrm{~N} \mathrm{~mm}^{-1} \mathrm{~s}\right)$. Salting makes internal protein changes which results in modification in fish texture and water holding capacity (Martinez et al., 2012). Acids also made texture firmer for smoked pre-treated fish because of acid penetration in fish flesh. There exists a moderate correlation between water activity and texture that shows the increased water activity decreasing work of shear $(\mathrm{r}=-0.75)$ and cutting strength $(\mathrm{r}=-0.78)$, it may also have an influence on microbiological parameters.

\section{Pre-treatment effect on microbiological parameters of smoked sprats}

Fish contains a lot of bacteria, but during processing some of them are inactivated, but some only start their activity. Shelf life of fresh or smoked sprats typically is some days, but using the pre-treatment it is possible to improve these microbiological parameters without significant sensory changes. Huong (2014) also researched that smoking inhibits the formation of toxins in products and reduce the growth of microorganism, due to lower water activity, or pre-treatment (salting, acid use) which creates a physical surface barrier for microbiological growth. The spoilage microflora of smoked fish can be impacted from smoking parameters or pretreatment method, but also time and temperature of storage, packaging material type are important.

Total plate count for fresh fish is allowed to be not more than $1 \times 10^{5} \mathrm{CFU} \mathrm{g}^{-1}$, but in smoked or smoked brined fish it should not exceed $1 \times 10^{4} \mathrm{CFU} \mathrm{g}^{-1}$ (“Технический регламент евразийского экономического союза 'о безопасности рыбы и рыбной продукции' (ТР ЕАЭС 040/2016) (Technical Regulation No. 040/2016 On safety of fish and fish products,"2016), pathogens Pseudomonas spp. (for fish typically including Pseudomonas aeruginosa, Pseudomona anguilliseptica "red spot disease") or moulds are not allowed in smoked fish, yeasts in smoked fish are allowed up to $1 \times 10^{3}$ CFU $\mathrm{g}^{-1}$, but need to follow Good Hygiene and Manufacturing practice program, because yeasts indicate the efficiency of cleaning and disinfection. Typically, yeasts are present in fresh fish, but during processing it can be additionally contaminated from processing environment and equipment (Bagge-Ravn et al., 2003). On the $1^{\text {st }}$ day after smoking the lowest TPC was determined in the sample pretreated with combination of sodium chloride and acetic acid. Sengun et al. (2021) reported that the acid has an inhibiting role for microbial growth. The lowest result for TPC after smoking and in storage was obtained using any of pretreatment methods even on the $2^{\text {nd }}$ week of storage only in the control sample rapid growth till $3.3 \times 10^{8} \mathrm{CFU} \mathrm{\textrm {g } ^ { - 1 }}$ was observed (Table 5).

Microbiological parameters during storage of smoked sprats

Table 5

\begin{tabular}{|c|c|c|c|c|c|c|c|c|c|c|c|}
\hline \multirow{2}{*}{$\begin{array}{l}\text { ID of } \\
\text { samples }\end{array}$} & \multicolumn{3}{|c|}{ Total plate count, $\mathrm{CFU} \mathrm{g}^{-1}$} & \multicolumn{2}{|c|}{$\begin{array}{l}\text { Pseudomonas } \\
\text { spp., CFU g }\end{array}$} & \multicolumn{3}{|c|}{ Yeasts, CFU g ${ }^{-1}$} & \multicolumn{3}{|c|}{ Moulds, CFU g ${ }^{-1}$} \\
\hline & $1^{\text {st }}$ day & $\begin{array}{c}1^{\text {st }} \\
\text { week }\end{array}$ & $2^{\text {nd }}$ week & $\begin{array}{l}1^{\text {st }} \\
\text { day }\end{array}$ & $1^{\text {st }}$ week & $\begin{array}{l}1^{\text {st }} \\
\text { day }\end{array}$ & $1^{\text {st }}$ week & $2^{\text {nd }}$ week & $\begin{array}{l}1^{\text {st }} \\
\text { day }\end{array}$ & $\begin{array}{c}1^{\text {st }} \\
\text { week }\end{array}$ & $2^{\text {nd }}$ week \\
\hline Control & $4.2 \times 10^{2}$ & $2.3 \times 10^{7}$ & $3.3 \times 10^{8}$ & $<10$ & $7.0 \times 10^{8}$ & $<10$ & $3.9 \times 10^{5}$ & $1.2 \times 10^{6}$ & $<10$ & $<10$ & $1.0 \times 10^{2}$ \\
\hline $\mathrm{Na}$ & $5.6 \times 10^{2}$ & $3.5 \times 10^{5}$ & $9.5 \times 10^{6}$ & $<10$ & $2.9 \times 10^{3}$ & $<10$ & $1.1 \times 10^{3}$ & $4.2 \times 10^{5}$ & $<10$ & $<10$ & $<10$ \\
\hline $3 \mathrm{Na} 2 \mathrm{Ca}$ & $3 \times 10^{2}$ & $2.6 \times 10^{3}$ & $7.2 \times 10^{5}$ & $<10$ & $1.0 \times 10^{3}$ & $<10$ & $1.5 \times 10^{2}$ & $9.5 \times 10^{4}$ & $<10$ & $<10$ & $<10$ \\
\hline $2 \mathrm{Na} 3 \mathrm{Ca}$ & $4.5 \times 10^{2}$ & $9.6 \times 10^{3}$ & $3.4 \times 10^{4}$ & $<10$ & $<10$ & $<10$ & $5.8 \times 10^{3}$ & $3.4 \times 10^{4}$ & $<10$ & $<10$ & $<10$ \\
\hline Ace & $7.0 \times 10^{1}$ & $5.2 \times 10^{2}$ & $1.2 \times 10^{5}$ & $<10$ & $<10$ & $<10$ & $3.7 \times 10^{2}$ & $8.3 \times 10^{4}$ & $<10$ & $<10$ & $<10$ \\
\hline NaAce & $6.0 \times 10^{1}$ & $2.6 \times 10^{4}$ & $2.1 \times 10^{6}$ & $<10$ & $<10$ & $<10$ & $2.5 \times 10^{6}$ & $1.7 \times 10^{6}$ & $<10$ & $<10$ & $<10$ \\
\hline CaAce & $8.0 \times 10^{1}$ & $6.4 \times 10^{2}$ & $4.4 \times 10^{5}$ & $<10$ & $<10$ & $<10$ & $7.5 \times 10^{2}$ & $2.5 \times 10^{5}$ & $<10$ & $<10$ & $<10$ \\
\hline
\end{tabular}


Some moulds and yeasts are salt tolerant, but using pretreatment (salts, acids) it is possible to decrease mould activity (Musa et al., 2018). Without pre-treatment yeasts started growing after the $1^{\text {st }}$ week $3.9 \times 10^{5} \mathrm{CFU} \mathrm{g}^{-1}$ while in the samples Ace or Na lowest growth $10^{2} \mathrm{CFU} \mathrm{g}^{-1}$. Moulds need water activity around 0.85 , but yeasts can grow at higher water activity (Tournas et al., 2001) and experiment showed similar results, because yeasts started growing after the $1^{\text {st }}$ week of storage and moulds after the $2^{\text {nd }}$ week of storage in the control sample because it had higher $\mathrm{pH}$. At the beginning, yeasts and moulds were below $<10 \mathrm{CFU} \mathrm{g}^{-1}$, but after one week the number of yeast colonies started to increase fast. Moulds stayed stable after the $1^{\text {st }}$ week. In the sample $3 \mathrm{Na} 2 \mathrm{Ca}$, the yeast count was the lowest $\left(1.5 \times 10^{2}\right.$ $\mathrm{CFU} \mathrm{g}^{-1}$, but in the sample NaAce the highest $2.5 \times 10^{6} \mathrm{CFU}$ $\mathrm{g}^{-1}$ and in $2^{\text {nd }}$ week the highest were also NaAce $1.7 \times 10^{6}$ CFU $\mathrm{g}^{-1}$ ). Using pre-treatment, it is possible to inhibit mould growth, because only in control sample after twoweek storage moulds $\left(1.0 \times 10^{2} \mathrm{CFU} \mathrm{g}^{-1}\right)$ were detected. Moulds are not allowed in processed fish, moulds metabolite products are mycotoxins, which are carcinogenic (Ayuba, Alhassan, \& Jimmy (2013)). Thus, using any of the selected pre-treatments, it is possible to reduce mould activity.

The microbiological parameters are the main factor that can have an impact on the smoked fish safety during its storage. Ayuba, Alhassan, \& Jimmy (2013) investigated bacterial pathogens, which may be transferred from fish to human beings include: Clostridium botulinum type E (botulism), Pseudomonas aeruginosa (wound infections), and Vibrio parahaemolyticus. González-Rodríguez et al. (2002) also confirmed Salmonella spp. and Listeria monocytogenes are food poisoning pathogens. In the current study, neither in freshly smoked nor stored fish these bacteria were detected. If fish contain Salmonella spp. or Listeria monocytogenes or other pathogen spores, only the application of sterilization or high pressure can destroy them; in smoking process the spores preserve their activity (Evelyn \& Silva, 2019). But if Listeria monocytogenes, Salmonella or Clostridium botulinum were in smoked sprats, there is a possibility to destroy them, because Mejlholm, Devitt, \& Dalgaard (2012) reported Listeria monocytogenes and Salmonella were not able to grow at $7.7{ }^{\circ} \mathrm{C}$ in brined (together lactic acid $0.32 \%$, acetic acid $0.28 \%$ of organic acids in the water phase) and drained modified atmosphere packaged shrimp that resembled commercial products with either acetic and lactic acids or benzoic, citric acids. Vibrio parahaemolyticus were not detected in the smoked fish, but using brine ( $0.21 \%$ benzoic acid, $1.65 \%$ citric acid, $0.10 \%$ sorbic acid and salt $3.30 \%$ percentage of chemicals (w/v) (Mejlholm, Devitt, \& Dalgaard (2012)) it is possible to inactivate also $V$. parahaemolyticus (at $2.2 \pm 0.4^{\circ} \mathrm{C}, \mathrm{pH} 4.0$ till $\mathrm{pH} 4.4)$. V. parahaemolyticus was reduced more than $3.0 \log \mathrm{CFU} \mathrm{g} \mathrm{g}^{-1}$ in mussels that were dipped in $2 \%(\mathrm{v} / \mathrm{v})$ lactic acid brine for $15 \mathrm{~min}$ (Belleggia et al., 2020). Using pre-treatment, it is possible to stop growth or inactivate $V$. parahaemolyticus pathogens. Clostridium perfingens was not detected in storage time of smoked sprats using pretreatment or without treatment; the same was observed for Escherichia coli (hygiene conditions) and Bacillus cereus, which was lower than $10 \mathrm{CFU} \mathrm{g}^{-1}$. Smoked sprats during storage did not contain any of these pathogens which means that no effect of the pre-treatment on pathogen growth can be observed according to this research.

Pseudomonas one day after smoking were less than 10 CFU g ${ }^{-1}$ (Abd El-Aziz, 2015) for all tested samples, but during storage the amount started to increase in the samples without pre-treatment; after the $1^{\text {st }}$ week it started to increase in the control sample as it had the highest $\mathrm{pH} 6.6$ and had the highest count $\left(7.0 \times 10^{8} \mathrm{CFU} \mathrm{g}^{-1}\right)$ after the $1^{\text {st }}$ week of storage. Duman et al. (2021) reported that Pseudomonas spp. stability and growth application vary with salt amount, temperature and $\mathrm{pH}$. Using acetic acid in combination with salt (Ace, NaAce, CaAce) or only salt with $\mathrm{CaCl}_{2}(2 \mathrm{Na} 3 \mathrm{Ca})$ it stays the same as one day after smoking <10 CFU g ${ }^{-1}$. Wang et al. (2014) research on freshwater grass carp during storage for 12 days indicated the increased Pseudomonas spp. growth from 3\% till 37\%. Sterniša et al. (2020) found correlation with fish weight and Pseudomonas species (Duman et al., 2021). Thus, the use of acetic acid or $\mathrm{CaCl}_{2}$ in majority of cases allowed to slow down the growth of Pseudomonas spp., and the product is acceptable for use in further production after one week of storage.

\section{Conclusions}

The use of brine ensures migration of salt and acid evenly in fish tissues, and it results in lower moisture content and lower $\mathrm{pH}$, which demonstrates the influence of pre-treatment on both physical and microbiological parameters. The pre-treatment can improve texture and colour of freshly smoked sprats. Textural parameters, such as cutting strength and work of shear are influenced by moisture content and $\mathrm{pH}$. Colour is affected both by salt content and $\mathrm{pH}$. The pre-treatment also ensures better microbiological parameters, which can ensure longer shelf life of smoked sprats, reducing the growth of TPC, moulds and yeasts. Pre-treated smoked sprats have higher salt content compared to fish without pre-treatment, and it ensures safer use of sprats in further processing, when different products from smoked fish (canned, pasteurized) are made. The pre-treatment in a brine, containing combination of sodium chloride and calcium chloride, improved textural parameters and ensured improvement of microbiological parameters of the smoked Baltic sprats.

\section{References}

Abbas, K. A., Saleh, A. M., Mohamed, A., \& Lasekan, O. (2009). The relationship between water activity and fish spoilage during cold storage: A review. Journal of Food, Agriculture and Environment, 7(3-4), 86-90.

Abbas, K. A., Mohamed, A., Jamilah, B., \& Ebrahimian, M. (2008). A review on correlations between fish freshness and $\mathrm{pH}$ during cold storage. American Journal of Biochemistry and Biotechnology, 4(4), 416-421. DOI: 10.3844/ajbbsp.2008.416.421

Abd El-Aziz, D. M. (2015). Detection of Pseudomonas spp. in chicken and fish sold in markets of Assiut City, Egypt. Journal of Food Quality and Hazards Control, 2(3), 86-89.

Ayuba, V. O., Alhassan, M. I., \& Jimmy, U. U. (2013). Assessment of the microbial load of smoked sardine ( Sardina pilchardus, Walbaum, 1792) sold in Makurdi Markets. International Journal of Current Microbiology and Apllied Sciences, 2(9), 277-287. 
Babikova, J., Hoeche, U., Boyd, J., \& Noci, F. (2020). Nutritional, physical, microbiological, and sensory properties of marinated Irish sprat. International Journal of Gastronomy and Food Science, 22(August), 100277. DOI: 10.1016/j.ijgfs.2020.100277

Bagge-Ravn, D., Ng, Y., Hjelm, M., Christiansen, J. N., Johansen, C., \& Gram, L. (2003). The microbial ecology of processing equipment in different fish industries - Analysis of the microflora during processing and following cleaning and disinfection. International Journal of Food Microbiology, 87(3), 239-250. DOI: 10.1016/S0168-1605(03)00067-9

Belleggia, L., Aquilanti, L., Ferrocino, I., Milanović, V., Garofalo, C., Clementi, F., Cocolin, L., Mozzon, M., Foligni, R., Naceur Haouet, M., Scuota, S., Frambos, M., Osimani, A. (2020). Discovering microbiota and volatile compounds of surströmming, the traditional Swedish sour herring. Food Microbiology, 91(September 2019). DOI: 10.1016/j.fm.2020.103503

Bjørnevik, M., Cardinal, M., Vallet, J. L., Nicolaisen, O., \& Arnarson, G. Ö. (2018). Effect of salting and coldsmoking procedures on Atlantic salmon originating from pre-or post rigor filleted raw material. Based on the measurement of physiochemical characteristics. LWT - Food Science and Technology, 91(January), 431-438. DOI: 10.1016/j.lwt.2018.01.047

Çağlak, E. (2015). Determination of shelf life of marinade and brine injected rainbout trout (Oncorhynchus mykiss, Walbum 1792) at refrigerator conditions. Journal of Food and Health Science, 1(4),199-2110. DOI: $10.3153 /$ jfhs 15019

Chan, S. S., Roth, B., Skare, M., Hernar, M., Jessen, F., Løvdal, T., Nordeng Jakobsen, A., Lerfall, J. (2020). Effect of chilling technologies on water holding properties and other quality parameters throughout the whole value chain: From whole fish to cold-smoked fillets of Atlantic salmon (Salmo salar). Aquaculture, 526 (February), 735381. DOI:

10.1016/j.aquaculture.2020.735381

Council of the European Union. Council Regulation (EC) No 2406/96 of 26 November 1996 laying down common marketing standards for certain fishery products. (1997).

Duman, M., Mulet, M., Altun, S., Saticioglu, I. B., Ozdemir, B., Ajmi, N., Lalucat, J., García-Valdés, E. (2021). The diversity of Pseudomonas species isolated from fish farms in Turkey. Aquaculture, 535(July 2020). DOI: 10.1016/j.aquaculture.2021.736369

Eizenberga, I., Terentjeva, M., Valciņa, O., Novoslavskij, A., Strazdina, V., Ošmjana, J., \& Bērziñš, A. (2015). Microbiological Quality of Raw Fish At Retail Market in Latvia. "Nordic View to Sustainable Rural Development", Proceedings of the 25th NJF Congress, (October 2014), 324-328. Retrieved from

https://www.bior.lv/sites/default/files/publikacijas/269_NJF 2015_Proceedings_Latvia-324-328_0.pdf

Evelyñ, \& Silva, F. V. M. (2019). Heat assisted HPP for the inactivation of bacteria, moulds and yeasts spores in foods: Log reductions and mathematical models. Trends in Food Science and Technology, 88(March), 143-156. DOI: 10.1016/j.tifs.2019.03.016

González-Rodríguez, M. N., Sanz, J. J., Santos, J. Á., Otero, A., \& García-López, M. L. (2002). Numbers and types of microorganisms in vacuum-packed cold-smoked freshwater fish at the retail level. International Journal of Food Microbiology, 77(1-2), 161-168. DOI: 10.1016/S0168-1605(02)00048-X

Huong, D. T. T. (2014). The effect of smoking methods on the quality of smoked Mackerel. United Nations University Fisheries Training Programme, Iceland [final project].

http://www.unuftp.is/static/fellows/document/huong13prf.p df

Kim, J. H., \& Lee, S. Y. (2021). Effect of $\mathrm{NaCl}$ addition on the antibacterial effectiveness of acetic acid and its salts against pathogenic bacteria. Food Control, 123(August), 107704. DOI:

10.1016/j.foodcont.2020.107704

Kuda, T., Yazaki, T., Takahashi, H., \& Kimura, B. (2013). Effect of dried and vinegar flavored squid products on acid resistance of Salmonella Typhimurium and Staphylococcus aureus. Food Control, 30(2), 569-574. DOI: 10.1016/j.foodcont.2012.09.011

Kwak, E., \& Lim, S. (2004). The effect of sugar, amino acid, metal ion, and $\mathrm{NaCl}$ on model Maillard reaction under pH control. Amino Acids, 27, 85-90.

Martinez, O., Salmerón, J., Guillén, M. D., Pin, C., \& Casas, C. (2012). Physicochemical, sensorial and textural characteristics of liquid-smoked salmon (Salmo salar) as affected by salting treatment and sugar addition. International Journal of Food Science and Technology, 47(5), 1086-1096. DOI: 10.1111/j.13652621.2012.02945.x

Mejlholm, O., Devitt, T. D., \& Dalgaard, P. (2012). Effect of brine marination on survival and growth of spoilage and pathogenic bacteria during processing and subsequent storage of ready-to-eat shrimp (Pandalus borealis). International Journal of Food Microbiology, 157(1), 16-27. DOI:

10.1016/j.ijfoodmicro.2012.04.006

Muceniece, D. (2020). Grūtās sarunās Latvija atsevišķām sugām panāk labākas zvejas iespējas Baltijas jūrā 2021. gadam, nekā sākotnēji tika piedāvāts (In difficult negotiations, Latvia achieves better fishing catch opportunities for certain species in the Baltic Sea by 2021 tha. Retrieved from

https://www.zm.gov.lv/zemkopibas-

ministrija/presei/grutas-sarunas-latvija-atseviskamsugam-panak-labakas-zvejas-iespejas-?id=11790

Musa, H., Kasim, F. H., Nagoor Gunny, A. A., \& Gopinath, S. C. B. (2018). Salt-adapted moulds and yeasts: Potentials in industrial and environmental biotechnology. Process Biochemistry, 69(February), 33-44. DOI: 10.1016/j.procbio.2018.03.026

Olayemi F., Raji A., \& Adedayo M. (2012). Microbiological quality of catfish (Clarias gariepinus) smoked with Nigerian Stored Products Research Institute (NSPRI) developed smoking kiln. International Research Journal of Microbiology (IRJM), 3(13), 2141-5463. Retrieved from http://www.interesjournals.org/IRJM

Parlapani, F. F., Mallouchos, A., Haroutounian, S. A., \& Boziaris, I. S. (2014). Microbiological spoilage and investigation of volatile profile during storage of sea bream fillets under various conditions. International Journal of Food Microbiology, 189, 153-163. DOI: 10.1016/j.ijfoodmicro.2014.08.006

Requirements for Food Quality Schemes, Procedures for the Implementation, Operation, Monitoring, and Control 
Thereof. (2014). Retrieved from

https://likumi.lv/ta/en/en/id/268347

Rizo, A., Fuentes, A., Fernández-Segovia, I., \& Barat, J. M. (2016). Feasibility of processing temperatures on the quality and shelf-life of smoke-flavoured cod. $L W T$ Food Science and Technology, 69, 546-553. DOI: 10.1016/j.lwt.2016.02.021

Ruiz-Alonso, S. A., Girón-Hernández, L. J., López-Vargas, J. H., Muñoz-Ramírez, A. P., \& Simal-Gandara, J. (2021). Optimizing salting and smoking conditions for the production and preservation of smokedflavoured tilapia fillets. Lwt, 138(December 2019). DOI: 10.1016/j.lwt.2020.110733

Sengun, I. Y., Yildiz Turp, G., Cicek, S. N., Avci, T., Ozturk, B., \& Kilic, G. (2021). Assessment of the effect of marination with organic fruit vinegars on safety and quality of beef. International Journal of Food Microbiology, 336(June 2020), 108904. DOI: 10.1016/j.ijfoodmicro.2020.108904

Sérot, T., Baron, R., Knockaert, C., \& Vallet, J. L. (2004). Effect of smoking processes on the contents of 10 major phenolic compounds in smoked fillets of herring (Clupea harengus). Food Chemistry, 85(1), 111-120. DOI: 10.1016/j.foodchem.2003.06.011

Sterniša, M., Bucar, F., Kunert, O., \& Smole Možina, S. (2020). Targeting fish spoilers Pseudomonas and Shewanella with oregano and nettle extracts. International Journal of Food Microbiology, 328(January), 108664. DOI: 10.1016/j.ijfoodmicro.2020.108664

Svanevik, C. S., \& Lunestad, B. T. (2011). Characterisation of the microbiota of Atlantic mackerel (Scomber scombrus). International Journal of Food Microbiology, 151(2), 164-170. DOI: 10.1016/j.ijfoodmicro.2011.08.016

Tahsin, K. N., Soad, A. R., Ali, A. M., \& Moury, I. J. (2017). A Review on the Techniques for Quality Assurance of Fish and Fish Products. International Journal of Advanced Research in Science, Engineering and Technology, 4(July). Retrieved from www.ijarset.com

Timberg, L. (2012). Spice-Cured Sprats Ripening, Sensory Parameters Development, and Quality Indicators. In Journal of Aquatic Food Product Technology (Vol. 23, Issue 2).
Timberg, L., Koppel, K., Kuldjärv, R., \& Paalme, T. (2011). Sensory and chemical properties of Baltic sprat (Sprattus sprattus balticus) and Baltic herring (Clupea harengus membras) in different catching seasons. Agronomy Research, 9(SPPL. ISS. 2), 489-494.

Toledo, R. T. (2008). Wood smoke components and functional properties. 55-61. DOI: 10.4027/isscp.2008.12

Tournas, V., Stack, E. M., Mislivec P. B., Koch, H. A., Bandler, R. (2001). BAM Chapter 18: Yeasts, Molds and Mycotoxins. Retrieved from

https://www.fda.gov/food/laboratory-methods-food/bamchapter-18-yeasts-molds-and-mycotoxins

Usydus, Z., Szlifder-Richert, J., \& Adamczyk, M. (2012). Variations in proximate composition and fatty acid profiles of Baltic sprat (Sprattus sprattus balticus). Food Chemistry, 130(1), 97-103. DOI: 10.1016/j.foodchem.2011.07.003

Wang, H., Luo, Y., Huang, H., \& Xu, Q. (2014). Microbial succession of grass carp (Ctenopharyngodon idellus) filets during storage at $4{ }^{\circ} \mathrm{C}$ and its contribution to biogenic amines'formation. International Journal of Food Microbiology, 190, 66-71. DOI: 10.1016/j.ijfoodmicro.2014.08.021

Wawire, M., Tsighe, N., Mahmud, A., Abraha, B., Wainaina, I., Karimi, S., \& Abdulkerim, Z. (2019). Effect of salting and pressing on quality characteristics of spotted sardine (Amblygaster sirm) during different storage conditions. Journal of Food Composition and Analysis, 79(February), 47-54. DOI: 10.1016/j.jfca.2019.03.008

Yamaguchi, K., Noumi, Y., Nakajima, K., Nagatsuka, C., Aizawa, H., Nakawaki, R., ... Van Chuyen, N. (2009). Effects of salt concentration on the reaction rate of Glc with amino acids, peptides, and proteins. Bioscience, Biotechnology and Biochemistry, 73(11), 2379-2383. DOI: 10.1271/bbb.90252

Yanar, Y., Çelik, M., \& Akamca, E. (2006). Effects of brine concentration on shelf-life of hot-smoked tilapia (Oreochromis niloticus) stored at $4^{\circ} \mathrm{C}$. Food Chemistry, 97(2), 244-247. DOI: 10.1016/j.foodchem.2005.03.043

Tehniceskii reglament evraziiskogo ekonomiceskogo souza "o bezopasnosti ryby i rybnoi produkcii” (TP EAЭC 040/2016) (Technical Regulation No. 040/2016 On safety of fish and fish products. (2016). Retrieved from https://docs.cntd.ru/document/420394425. (in Russian)

\section{Acknowledgment}

This work was supported by the programme "Strengthening research capacity in the Latvia University of Life Sciences and Technologies" project Z43 and fish producing company SIA "NS ESTATE”. 